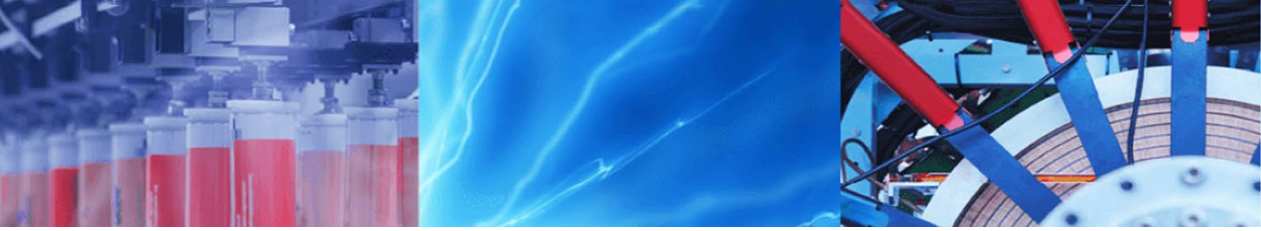

Research Article

\title{
Particulate and trace metal emission from mosquito coil and cigarette burning in environmental chamber
}

\author{
Neha Khandelwal ${ }^{1} \cdot$ Rahul Tiwari $^{1,2} \cdot$ Renuka Saini $^{1} \cdot$ Ajay Taneja $^{1}$
}

(c) Springer Nature Switzerland AG 2019

\begin{abstract}
The objectives of this study were to characterize the emissions of indoor air pollutants from the burning of mosquito coils and cigarettes using a closed environmental chamber, to compare air pollutant emissions from different types of mosquito coils and cigarettes, which are popular in Indian market; to quantify emissions from burning of mosquito coils and cigarettes with respect to particulate matter $\left(\mathrm{PM}_{0.25}, \mathrm{PM}_{1.0}, \mathrm{PM}_{2.5}\right.$, and $\left.\mathrm{PM}_{10}\right)$ and metals. Smoke contains several thousands of chemicals and heavy metals, and most of them are formed during the burning of cigarettes and burning of mosquito coils. The present study attempts to characterize the emissions of PM and heavy metals from different types of mosquito coils and cigarettes burning which were monitored in three different phases pre-burning, during burning, and post-burning. Five different brands of cigarette and mosquito coils were taken which are commonly used in India. Samples collected were analyzed for heavy metal (Al, $\mathrm{Cu}, \mathrm{Zn}, \mathrm{Cd}, \mathrm{Cr}, \mathrm{Mn}, \mathrm{Ni}, \mathrm{Pb}, \mathrm{V}$, Se, and $\mathrm{Sc}$ ) concentration using ICP-AES, and the morphological analysis was performed with the help of scanning electron microscopy. The trend of concentration of PM in mosquito coil is followed as $\mathrm{M} 1>\mathrm{M} 3>\mathrm{M} 2>\mathrm{M} 4>\mathrm{M} 5$, and in a cigarette it was $\mathrm{C} 5>\mathrm{C} 2>\mathrm{C} 4>\mathrm{C} 3>\mathrm{C} 1$. The study suggests that burning of mosquito coil and a cigarette in the indoor environment emits quiet higher respirable $\mathrm{PM}$, which may on prolonged exposure lead to illnesses. The maximum concentration of $\mathrm{Al}, \mathrm{Cu}, \mathrm{Zn}$ and $\mathrm{Mn}$ was found higher, while that of $\mathrm{Cd}, \mathrm{V}$ and $\mathrm{Se}$ was below the detection limit in both types of samples. Calculations were made to explore expected cancer and non-cancer risks, using published toxicity potentials for three metals ( $\mathrm{Cr}$, $\mathrm{Pb}$, and Ni). Hazards quotient values for adults were under safe limit. The order of excess cancer risk for the carcinogenic elements follows the similar trend for both cigarette and mosquito coils in adults; it was observed as $\mathrm{Pb}<\mathrm{Ni}<\mathrm{Cr}$. Overall, the cancer risk was below the acceptable level $\left(10^{-4}-10^{-6}\right)$.
\end{abstract}

Keywords Mosquito coil $\cdot$ Cigarette $\cdot$ Heavy metals $\cdot$ Particulate matter $\cdot$ Cancer risk

\section{Introduction}

The apprehension governing the concept of indoor air quality has undergone an electrifying elevation in recent years owing to the recognition of different pollutants originating from diverse indoor and outdoor sources that truly rely upon the procedures and actions occurring within the environment [1]. Indoor air pollution has been tagged in the list of top five environmental risks by US Environmental Protection Agency (USEPA) [2]. The heavy metals in particulate matter which were inhaled in elevated concentration are suggested to impact harsh toxic and carcinogenic effects on humans [3-5]. Nevertheless, illness related to respiratory and cardiovascular issues, even potential carcinogenicity, is also a direct consequence of long-term exposure to the contaminant residing in indoor air [6]. The smoke emitted from their combustion releases particulate matter and the combustion leads to the production of a large amount of smoke, which when inhaled poses a wider health hazards [7]. Not only day to day but also an

Ajay Taneja, ataneja5@hotmail.com | 'Department of Chemistry, Dr. B. R. Ambedkar University, Khandari Campus, Agra 282002, India. ${ }^{2}$ Department of Chemistry, GLA University, Mathura 281406, India.

SN Applied Sciences (2019) 1:441 | https://doi.org/10.1007/s42452-019-0435-2

Received: 3 December 2018 / Accepted: 1 April 2019 / Published online: 10 April 2019 
hour-to-hour basis of exposure is observed to wield diminutive variations in atmospheric metal concentration, which leads to the fact that reducing particulate and related metal pollution to numerous sufficient levels is an essential environmental matter [3]. Among them, fine particles have a higher burden of toxic metals than coarse particles owing to their higher penetration power ability to reach lungs $[8,9]$. The major source of particles in the indoor air is mainly derived from the smoking of cigarettes, a worldwide habit [10]. Cigarettes are produced from tobacco leaves cultivated in different parts of the world. Tobacco use and in particular smoking have been worldwide accepted to be a major cause of preventable death among adults [11]. Among which the smoke emitted from tobacco use has sourced anthropogenic pollution in the indoor environment [12]. The occurrence of an additive compound such as nicotine is a chief cause for cigarette habituation encouraged by factors, viz., height and mass production, and social acceptance as it is readily available, relatively cheap, and lightweight. In many countries, cigarette smoking has been identified as a major serious health issue and contributor to high mortality and morbidity rate of both smokers and passive smokers [13]. The current trend of incorporation of newly synthesized and the addition of flavors, casing materials and other ingredients that have the potential to beautifully modify the quantity and quality of the smoke yielded has led to the large evaluation of the cigarette design over the last decades [14]. Many different classes of chemicals are present in more than 4000 chemicals, found in tobacco smoke [15]. Among which, particulate matter, carbon monoxide, and nicotine bear a special attention (as hazardous substances in tobacco smoke) from research [10]. The second-hand smoke has been implicated in a large number of studies to be responsible for mortality of 3000 non-smoking adults in lung cancer [16]. The percentage of youth (15-24 years) involved in daily tobacco use accounted for $15 \%$, while those engaged in tobacco smoke frequently and on daily basis accounted for $23 \%$ [17]. As a result of direct inhalation of toxic particulate elements in cigarette smoke, there is an increase in health hazards to the smokers, and nevertheless, non-smokers are at direct stake [17]. The cigarette delivery of elements to mainstream smoke can be addressed as a combination of two factors, a number of these elements present in tobacco and their transfer rate, which is specific to element speciation and is impacted by cigarette design [18]. Toxic particulate elements present in cigarette smoke cause health threats to the life of smokers through inhalation and at the same time increase health risk to non-smokers present in the vicinity of smokers because of their exposure. As per the records in 2008, about 1.38 million people die of lung cancer annually worldwide, which accounts for about $18.2 \%$ of the total number of cancer deaths [19]. The bio-accumulation, i.e., the tendency to increase in concentration over time in heavy metals, proves hazardous as compared to their current amount present in the environment [20]. Increase in tobacco smoking has been associated with health implications; hence, there is a need for research on the heavy metal contents of tobacco [13]. Malaria and dengue fever are the most common decreases spread by mosquitoes in tropical countries. Usage of mosquito repellent coils, mats, aerosols spray, and liquid vaporizers are the most common way employed in the control of mosquitoes in domestic households. These mat and liquid vaporizers cut the burning smell, whereas the burning of mosquito coil releases continuous smoke along with the vigorous material used [21]. The prevalence of burning of mosquito coil in indoor and outdoor is common globally with higher wings extended in parts of East Asia. The chemicals found in mosquito smoke are very complex [22]. Heavy metals including $\mathrm{Cd}, \mathrm{Zn}, \mathrm{Pb}$, and organic compounds, viz., phenol, $O$-cresol and allethrin, account for the category of particles generated by combustion of mosquito coils [23]. The use of insecticides evaporated with the smoke emitted from burning of mosquito coil prevents the entry of mosquitoes into the room [24]. Pyrethroids constitute as an essential commonly found active ingredient in the coil that proves effective against genera of mosquitoes including Anopheles, Mansonia, and Aedes. The smoke emitted from mosquito coil is chemically complex in nature containing small particles $(<1 \mu \mathrm{m})$ besides metal fumes and vapors that have the capability to contact the alveolar region of the lung and thus prove hazardous to parents and their children when exposed [25]. An extensive literature exists concerning the particle size allocation of trace elements in PM and also their related effect on their health globally. Agbandji et al. [26] compared the levels of $\mathrm{Pb}, \mathrm{Cd}, \mathrm{Ni}$, and As in some cigarettes sold in Benin and France. A study of Jung et al. [27] focused on the elemental ( $\mathrm{Pb}, \mathrm{As}, \mathrm{Zn}, \mathrm{Cd}$, and $\mathrm{Cu}$ ) concentrations in different cigarette brands commonly sold in Korea and UK. As an extension, the concentration of ( $\mathrm{Pb}, \mathrm{Cd}, \mathrm{As}, \mathrm{Hg}, \mathrm{Ni}, \mathrm{Cr}, \mathrm{Sn}$, and $\mathrm{Sb})$ was analyzed in mosquito coil and ash by Phal [21]. Lee and Wang [23] illustrates the emission of air pollutants from candles and mosquito coils burning in a large environmental test chamber. Lin et al. [22] found out the trace metals, viz., $\mathrm{Pb}$, $\mathrm{Cr}, \mathrm{Ni}, \mathrm{Co}, \mathrm{Tl}, \mathrm{Cd}$, and $\mathrm{Mn}$ in three brands of mosquito coils in Taiwan. A study carried out by Roy et al. [28] recommended that the particle size distribution of particulate matter including its chemical analysis primarily sourced from a cigarette, incense stick, mosquito coil, and dhoop combustion is prevalent in Indian urban homes. Additionally, the pre-burning, burning, and post-burning phases of incenses (agarbatti and dhoop) and mosquito coil as a subject were considered in the monitoring of indoor 


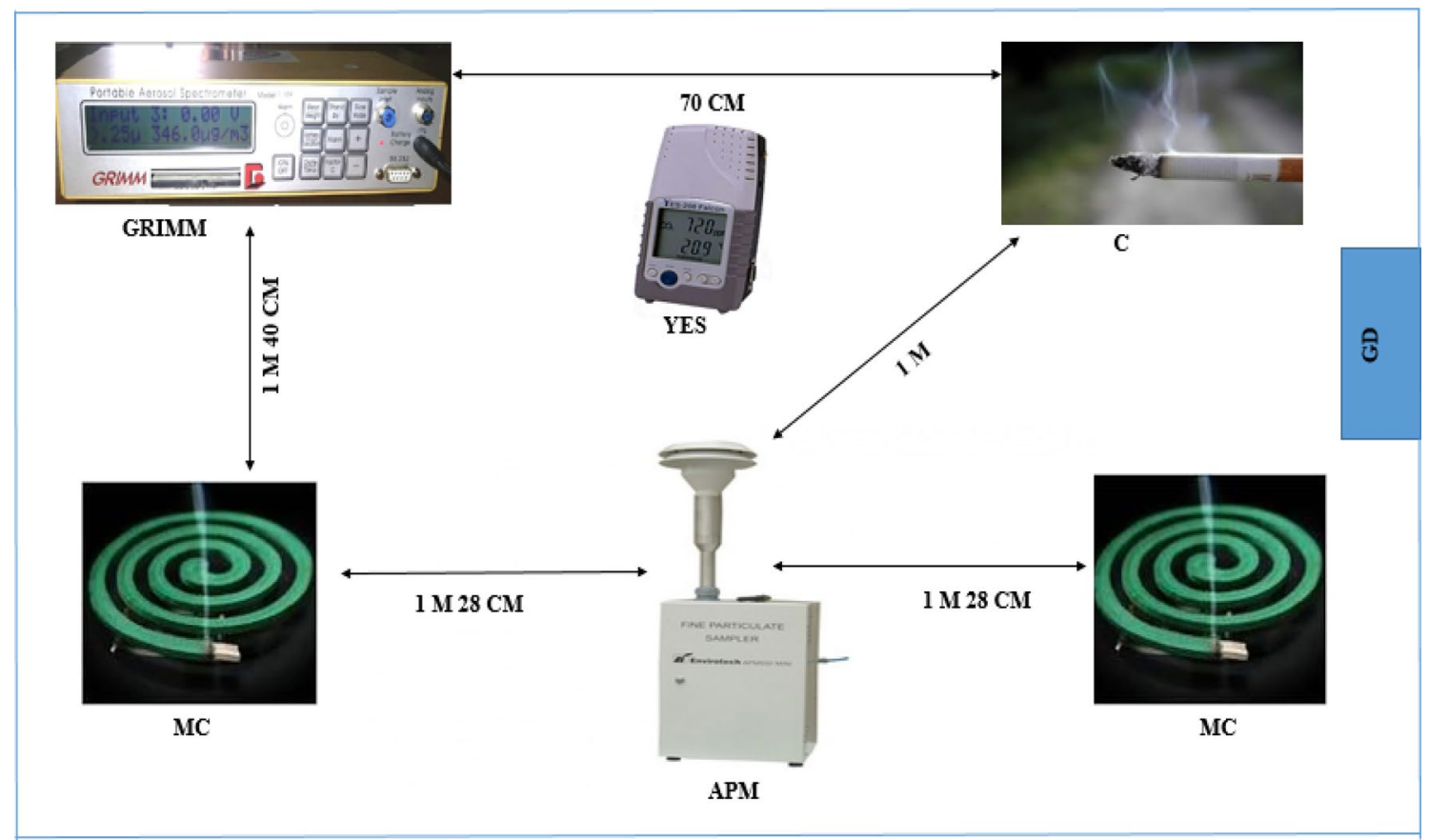

Fig. 1 Schematic diagram of the experimental chamber

particulate matter by Kumar et al. [29]. But, data available lack the morphology and toxicity of metals associated with size-segregated particulate matter. To find out the particle size and shape, a qualitative and quantitative clarification of the particles for thorough toxicological assessment of PM and its allied elements is necessary [30]. Thus, the primary objectives of this paper lie in determination of sizesegregated $\mathrm{PM}$ concentration and also the toxic heavy metals ( $\mathrm{Cu}, \mathrm{Mn}, \mathrm{Cd}, \mathrm{Pb}, \mathrm{Cr}, \mathrm{Ni}, \mathrm{Sn}, \mathrm{Al}, \mathrm{Se}, \mathrm{Zn}$, and $\mathrm{V})$ in fine particulate matter emitted from mosquito coils and cigarettes smoke and also its crush, released in air using a large environmental chamber. We also observed the morphology of the air samples of mosquito coils and cigarettes using SEM technique. In addition, evaluation of risk assessment related to particulate pollutant is also done. We have taken both mosquito coils and cigarettes in the present study because they have the most combustible activities apart from cooking in the household.

\section{Materials and methods}

\subsection{Materials}

The five most available brands of mosquito coils (Mortein, Maxo, All out, Good knight, and Good knight Neem) and five brands of cigarette (Black, Classic, Wills Navy cut, Capstan, and Gold flakes) currently obtainable in Indian market were purchased from the local market of Agra.

\subsection{Chamber experiments}

The experiments were conducted in room environmental test chamber (length $=6.01 \mathrm{~m}$, height $=3.65 \mathrm{~m}$, width $=3.25 \mathrm{~m}$ with $71.29 \mathrm{~m}^{3}$ effective volume) maintained at controlled environmental conditions (Fig. 1). A portable Yes-206 falcon IAQ monitor was further more employed to monitor the temperature, $\mathrm{CO}_{2}$ level, and ventilation rate within the chamber. The average temperature of the chamber was $31.14 \pm 0.5^{\circ} \mathrm{C}$, ventilation rate was $24.62 \pm 6.7 \mathrm{l} / \mathrm{P} / \mathrm{S}$, and the $\mathrm{CO}_{2}$ level was $603 \pm 54.7 \mathrm{ppm}$. The $\mathrm{PM}_{0.25}, \mathrm{PM}_{1.0}$, $\mathrm{PM}_{2.5}$, and $\mathrm{PM}_{10}$ concentration levels were measured with GRIMM Aerosol Spectrometer (GRIMM 1.109, flow rate $2 \mathrm{l} / \mathrm{min}$ ) for the present study. The fine particulate matter $\left(\mathrm{PM}_{2.5}\right)$ samples were collected with fine particulate dust sampler (APM 550 Envirotech). It is designed to ensnare medium-sized (between 2.5 and 10 microns) particles. A 37-mm-diameter glass fiber (GF/A) paper wrapped up in silicon oil was used to avoid sampling error due to bouncing of small-sized particulates from impaction surface. For sustaining a stable flow rate of $16.67 \mathrm{l} / \mathrm{min}$, oil-less rotator pump to produce the suction pressure and critical flow control orifice (as recommended by USEPA) was used in APM 550. Polytetrafluoroethylene (PTFE Teflon) filter paper of $47 \mathrm{~mm}$ diameter was used to collect fine particulate matter $\left(\mathrm{PM}_{2.5}\right)$ (http://www.envirotechindia.com/apm$550 \mathrm{html}$ ). A blank $\mathrm{PM}_{2.5}$ sample filter was used to collect background samples before incense combustion. All the instruments were calibrated before used. 


\subsection{Sampling methods and analysis}

Each single coil has the average weight of $17.85 \mathrm{~g}$ with an outermost diameter of $14 \mathrm{~cm}$. The distance between mosquito coil and APM was $1.28 \mathrm{~m}$, whereas that of mosquito coil and GRIMM was $1.40 \mathrm{~cm}$. In the first stage, sampling was done by GRIMM and APM 550 for half an hour without burning mosquito coil. After half an hour, two mosquito coils were lit and left to burn for about $5 \mathrm{~h}$. In which $6 \mathrm{~cm}$ was lit during the sampling time and after sampling $8 \mathrm{~cm}$ was left. After $5 \mathrm{~h}$, instruments were run without burning coils for half an hour. A pre-cleaned porcelain dish was used to ground one single coil. A polyethylene bag was used to store the homogenized samples for analysis. Numbers of sticks of cigarette were taken according to its weight for burning such as ten sticks of Gold flakes $=7.79 \mathrm{~g}$; seven sticks of Wills navy cut $=7.69 \mathrm{~g}$; eight sticks of classic $=7.32 \mathrm{~g}$; eight sticks of Black $=7.37 \mathrm{~g}$; and ten sticks of Capstan $=7.75 \mathrm{~g}$ (Fig. 4). The average weight of cigarettes burn was $7.58 \mathrm{~g}$. Each single stick has an average weight of $0.83 \mathrm{~g}$. According to a survey, a smoker consumes $30 \%$ of his cigarettes from a one-pack-a-day in the duration of 4-h intervals in the house atmosphere. With no upsetting of the room's environment cigarettes were lit and put back in order. Since it took approximately $10 \mathrm{~min}$ to complete the smoking procedure, a typical hour of sampling consisted of 20 min of no smoking followed by a 10 min smoking period and so on with this type of repeating cycle (http://www.who.int/tobacco/media/en/ rickert.pdf). Same numbers of sticks were grounded. Polyethylene bags were used to position the homogenized samples for analysis.

\subsubsection{Sample extraction for filter paper}

Extraction was done for the determination of metals using acid extraction by aqua-regia $\left(\mathrm{HNO}_{3}\right.$ and $\mathrm{HCl}$ in ratio $\left.1: 3\right)$ on a hot plate at $20^{\circ}$ to $30^{\circ} \mathrm{C}$ for 1 and half an hour in a $50-\mathrm{ml}$ measuring beaker, and then, the extracted samples were filtered by Whatman filter paper. Lastly, we diluted the extract up to $40 \mathrm{ml}$ with de-ionized water as well as stored at $4{ }^{\circ} \mathrm{C}$ in refrigerators. All samples were analyzed for 11 metals $\mathrm{Cu}, \mathrm{Mn}, \mathrm{Mg}, \mathrm{Ni}, \mathrm{Zn}, \mathrm{Cr}, \mathrm{Cd}, \mathrm{Fe}, \mathrm{As}, \mathrm{Pb}$, and $\mathrm{Cu}$ with ICP-AES (inductive coupled plasma-atomic emission spectrometer). The quality controls, acid extraction or digestion method with integrated reagents grade, blank sample and standards reference materials are described elsewhere [6].

\subsubsection{Sample extraction for crushed cigarettes}

The weighed $0.5 \mathrm{~g}$ cigarette tobacco that has been dried and grounded systematically and homogenized was placed in a 100-ml flat-bottomed flask. Five milliliters of concentrated $\mathrm{HNO}_{3}$ acid was added, and the flask was enclosed with a watch glass and allowed to stand overnight. The covered flask was placed on a hot plate with a temperature controller and heated at $200{ }^{\circ} \mathrm{C}$ for $30 \mathrm{~min}$. The flask was removed and cooled, and $2 \mathrm{ml}$ of $30 \% \mathrm{H}_{2} \mathrm{O}_{2}$ was added and digested at the same temperature and time in a similar way. This was repeated for complete digestion. The digest was allowed to dry up to 1 to $2 \mathrm{ml}$ at $150{ }^{\circ} \mathrm{C}$. Then, $5.0 \mathrm{ml}$ of $1 \% \mathrm{HNO}_{3}$ was put into digest residue and filtered quantitatively through Whatman filter paper into a $25-\mathrm{ml}$ volumetric flask and made up to the volume with de-ionized water. This was consequently analyzed for $\mathrm{Cd}, \mathrm{Al}, \mathrm{Cu}, \mathrm{Cr}, \mathrm{Mn}, \mathrm{Pb}, \mathrm{Ni}, \mathrm{Se}, \mathrm{Sn}, \mathrm{Zn}$, and $\mathrm{V}$ using ICP-AES [31].

\subsubsection{Sample extraction for crushed mosquito coils}

$0.2 \mathrm{gm}$ of both grounded coil were digested with $20 \mathrm{ml}$ mixed acid (concentrated $\mathrm{H}_{2} \mathrm{SO}_{4} / \mathrm{HNO}_{3} / \mathrm{HCLO}_{4}=5: 1: 0.5$ ) at $150^{\circ} \mathrm{C}$ for $24 \mathrm{~h}$. The extracts were diluted to $50 \mathrm{ml}$, and the concentrations of $\mathrm{Cu}, \mathrm{Al}, \mathrm{Cr}, \mathrm{Cd}, \mathrm{Pb}, \mathrm{Mn}, \mathrm{Se}, \mathrm{Ni}, \mathrm{Sn}, \mathrm{Zn}$, and $\checkmark$ were analyzed using ICP-AES [32].

\subsection{Human exposure and health risk assessment model}

Calculations have been made for carcinogenic and noncarcinogenic risk which was originated by the exposure to particle-bound metals in air. Techniques were employed to solve the exposure potential dosage in inhalation pathway, followed by risk assessment techniques. Uses of risk assessment are to describe the nature and magnitude of health risk to humans from chemical contaminants and other stressors that may be present in the environment. It is to evaluate the frequency and magnitude of human exposure that may occur as a consequence of contact with the contaminated medium, both now and in the future.

\subsubsection{Exposure dose}

The potential dose is the quantity inhaled. Potential average daily dose $\left(A D D_{\text {pot }}\right)(\mu \mathrm{g} / \mathrm{kg}$-day) may be estimated using an equation. The dose relies upon the rate of inhalation and contaminant concentration (i.e., $\mathrm{PM}_{0.25}, \mathrm{PM}_{1.0}$, $\mathrm{PM}_{2.5}$, and $\mathrm{PM}_{10}$, heavy metals) and perhaps arranged to body weight as a function of time. It can be inured to average seasonal or intermittent exposure patterns over one or more years. The formula is given as follows:

$\mathrm{ADD}_{\text {pot }}=[C \times \mathrm{IR} \times \mathrm{ED}] /[\mathrm{BW} \times \mathrm{AT}]$ 
where $C=$ contaminant concentration $\left(\mu \mathrm{g} / \mathrm{m}^{3}\right)$, IR = inhalation rate $\left(\mathrm{m}^{3} /\right.$ day), $E D=$ exposure duration (days), $\mathrm{BW}=$ body weight $(\mathrm{kg}), A T=$ number of days over which the exposure is averaged (days).

The principles of toxicity for health effects perhaps were calculated in stipulations of unit risk inhalation slope factor (SFI) when exposure was through inhalation. The unit risk specifies the probability for a health effect to happen if the impurity has a unit increase (per $\mu \mathrm{g} / \mathrm{m}^{3}$ ) in concentration; as earlier stated, the slope factor can be defined by the unit risk utilizing the following equation:

$$
\begin{aligned}
\mathrm{SFI}= & \text { Unit Risk }\left(\mu \mathrm{g} / \mathrm{m}^{3}\right)^{-1} \times \text { Body Weight }(\mathrm{kg}) \\
& \times \text { Inhalation Rate }\left(\mathrm{m}^{3} / \text { day }\right)^{-1}
\end{aligned}
$$

The SFl is given in units of (per $\mu \mathrm{g} / \mathrm{kg}$-day). These calculations are usually an assessment of the additional possibility of a health effect (i.e., cancer) from a unit dosage of an impurity over a period of time. Hence, Eq. (1) for individual risk measurement becomes [33].

$R_{\mathrm{i}}=\mathrm{ADD}_{\text {pot }} \times \mathrm{SFI}$

\subsubsection{Non-carcinogenic health risk}

Hazard quotient $(\mathrm{HQ})$ and hazard index $(\mathrm{HI})$ are inured to find out the non-cancer risk of heavy metals in ambient particles. As the average daily dose for three pathways has been estimated, $\mathrm{HQ}$ can be calculated from the following equation $[34,35]$.

$\mathrm{HQ}=\mathrm{ADD} / \mathrm{RfD}$

where $\mathrm{HQ}=$ hazard quotient, $\mathrm{ADD}=$ average daily dose, $\mathrm{RfD}=$ reference dose.

The reference dose is an approximation of maximum allowable risk on the human population through daily exposure received into account of the sensitive group throughout a lifetime. If $\mathrm{HQ}<1$, it implies no adverse impact on health. If $\mathrm{HQ}>1$, then there is a risk that the exposure pathway may unfavorably have an effect on human health [36].

\subsubsection{Excess cancer risk}

Excess cancer risks (ECRs) have evaluated the additional possibility of a person developing cancer over a lifespan as a result of total exposure to the potential carcinogen. ECR is calculated by applying the following equation $[37,38]$.

$\mathrm{ECR}=\mathrm{C} * \mathrm{ET} * \mathrm{EF} * \mathrm{ED} * \mathrm{IUR} / \mathrm{AT}$

where $C$ is the concentration of pollutant $\left(\mathrm{mg} / \mathrm{m}^{3}\right)$, IUR is the inhalation unit risk $\left(\mathrm{mg} / \mathrm{m}^{3}\right)$, AT is the average time for carcinogens (70 years 365 days/year $24 \mathrm{~h} /$ day), ET is the exposure time which in this study was $6 \mathrm{~h} /$ day in mosquito coil and 5 or $6 \mathrm{~h} /$ day in cigarettes. Carcinogens are considered non-threshold, meaning exposure of any amount of carcinogens will likely lead to cancer and the secure amount of carcinogens is "zero." The data on the carcinogenic types and the inhalation unit risk of the metals are acquired from the USEPA database for integrated information risk system (IRIS). The reference values of carcinogenic risk by dermal exposure and ingestion were not provided by the USEPA, so in our study, we have examined the only carcinogenic risk of metals via inhalation pathway [34]. If the value of risk drops between the ranges $\left(10^{-6}-10^{-4}\right)$, then the contamination likely does not produce carcinogenic risk [38].

\section{Result and discussion}

\subsection{Level of $\mathrm{PM}_{2.5}$}

The concentration of $\mathrm{PM}_{0.25}, \mathrm{PM}_{1.0}, \mathrm{PM}_{2.5}$, and $\mathrm{PM}_{10}$ was carried out for 5 days for five different brands of mosquito coils. As shown in Fig. 2, the higher concentrations of $\mathrm{PM}_{0.25}, \mathrm{PM}_{1.0}, \mathrm{PM}_{2.5}$, and $\mathrm{PM}_{10}$ were recorded for
Fig. 2 Average of PM mass concentration for five brands of mosquito coil during preburning, burning, and postburning

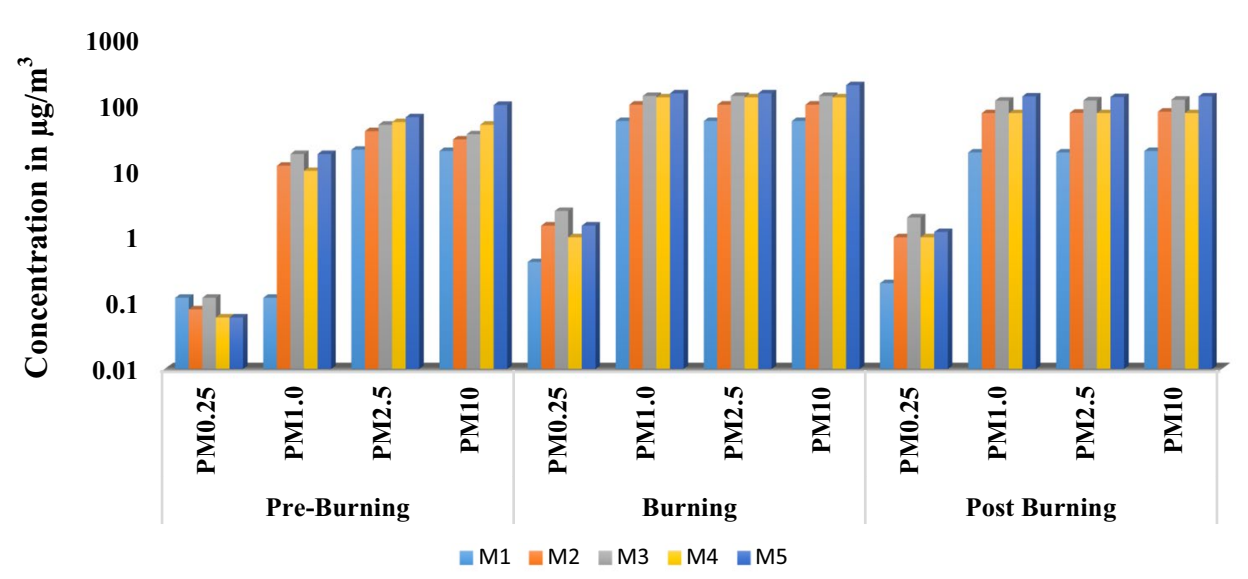

SN Applied Sciences A SPRINGer Nature journal 
sample M1 and lower concentration was found in sample M5. Average concentration of different sizes of PM was observed as $\mathrm{M} 1>\mathrm{M} 3>\mathrm{M} 2>\mathrm{M} 4>\mathrm{M} 5$. In the present study, higher average concentration of all size fractions of $\mathrm{PM}$ was found in burning phase as $\mathrm{PM}_{0.25}(1212.5 \%)$, $\mathrm{PM}_{1.0}$ (1833.3\%), $\mathrm{PM}_{2.5}$ (830.42\%), and $\mathrm{PM}_{10}$ (444.89\%) than that in pre-burning and post-burning phases, and it was $\mathrm{PM}_{0.25}(23.23 \%), \mathrm{PM}_{1.0}(65.33 \%), \mathrm{PM}_{2.5}$ (63.05\%) and $\mathrm{PM}_{10}(60.96 \%)$ lower, respectively, in post-burning phase. It is shown in all samples that the concentration piercingly augmented and attained the highest at the end of the burning period, and turned down during the post-burning period. The results are in line with earlier studies $[24,29]$ done on agarbatti, dhoop, and mosquito coil in the indoor environment. This study also contradicts the earlier study [32] where the average results of $\mathrm{Cd}(82.66 \%), \mathrm{Cr}(73.26 \%)$, and $\mathrm{Pb}$ (78.34\%) were found higher, while that of $\mathrm{Fe}, \mathrm{Ni}$, and $\mathrm{Zn}(25.9 \%, 29.88 \%$ and $31.52 \%)$, respectively, were lower from the burning coil. Sampling for the determination of $\mathrm{PM}_{0.25}, \mathrm{PM}_{1.0}, \mathrm{PM}_{2.5}$, and $\mathrm{PM}_{10}$ was carried out for 5 days for five different brands of cigarette. As shown in Fig. 3, average values of $\mathrm{PM}_{0.25}, \mathrm{PM}_{1.0}, \mathrm{PM}_{2.5}$, and $\mathrm{PM}_{10}$ were found 84.3, 141.05\%, $130.66 \%$, and $122.47 \%$ higher, respectively, from nonburning to burning phase in cigarette samples. During the burning period, the highest and lowest average mass concentrations of $\mathrm{PM}_{0.25}$ and $\mathrm{PM}_{1.0}$ occurred in samples $C 5\left(0.80 \mu \mathrm{g} / \mathrm{m}^{3}\right.$ and $\left.140.44 \mu \mathrm{g} / \mathrm{m}^{3}\right)$ and $\mathrm{C} 1$ $\left(0.40 \mu \mathrm{g} / \mathrm{m}^{3}\right.$ and $\left.47.45 \mu \mathrm{g} / \mathrm{m}^{3}\right)$, respectively, while the highest and lowest average mass concentrations of $\mathrm{PM}_{2.5}$ and $\mathrm{PM}_{10}$ occurred in samples $\mathrm{C} 5\left(149.33 \mu \mathrm{g} / \mathrm{m}^{3}\right.$ and $\left.174.34 \mu \mathrm{g} / \mathrm{m}^{3}\right)$ and $C 4\left(51.70 \mu \mathrm{g} / \mathrm{m}^{3}\right.$ and $53.80 \mu \mathrm{g} /$ $\mathrm{m}^{3}$ ), respectively; whereas during the non-burning phase, the highest average mass concentration of $\mathrm{PM}_{0.25}$ and $\mathrm{PM}_{1.0}$ occurred in sample $\mathrm{C} 5\left(0.80 \mu \mathrm{g} / \mathrm{m}^{3}\right.$ and $\left.39.72 \mu \mathrm{g} / \mathrm{m}^{3}\right)$, respectively, the and lowest in samples $\mathrm{C} 4\left(0.20 \mu \mathrm{g} / \mathrm{m}^{3}\right)$ and $\mathrm{C} 3\left(22.47 \mu \mathrm{g} / \mathrm{m}^{3}\right)$, respectively.
The highest and lowest average mass concentrations of $\mathrm{PM}_{2.5}$ and $\mathrm{PM}_{10}$ occurred in samples $\mathrm{C} 5\left(45.95 \mu \mathrm{g} / \mathrm{m}^{3}\right.$ and $\left.53.78 \mu \mathrm{g} / \mathrm{m}^{3}\right)$ and $\mathrm{C} 3\left(24.38 \mu \mathrm{g} / \mathrm{m}^{3}\right.$ and $26.20 \mu \mathrm{g} /$ $\mathrm{m}^{3}$ ), respectively. In India, indoor environmental air quality standards have not been recommended yet; therefore, we compare our results with that of the World Health Organization (WHO) [39], 2006 standards. Overall, the values of $\mathrm{PM}_{2.5}$ and $\mathrm{PM}_{10}$ concentrations were found lower from the permissible limit in sample M5, while it was found higher in the rest of the samples of mosquito coil and cigarette samples. The trace elements found in mosquito coil and its crush, cigarettes and their crush are shown in Tables 1 and 2, respectively. Concentrations of metals were found many fold times lower in air samples in comparison with crush samples of mosquito coil and cigarette. ICP-AES technique was inured to determine the concentration of heavy metals in fine particulate matter. $\mathrm{Cd}, \mathrm{V}, \mathrm{Se}$, and $\mathrm{Tn}$ are not detected in any brands of mosquito coil and cigarette in the air sample. The maximum concentration of Al was observed and minimum concentration of $\mathrm{Ni}$ and $\mathrm{Pb}$ was found in crush samples of mosquito coil and cigarette, respectively, whereas the minimum concentration of $\mathrm{Mn}$ was found in air samples of mosquito coil and cigarette. The concentrations of $\mathrm{Al}, \mathrm{Cu}, \mathrm{Mn}, \mathrm{Cr}$, and Ni were of almost the same order in mosquito coil and cigarette samples. Results were found to be similar to [40] that Fe concentrations were highest in all the brands compared to the other metals, while the cadmium concentration was lowest in all the four brands of cigarette. The concentration of $\mathrm{Zn}$ was found however higher in mosquito coil samples in comparison with cigarette samples. Concentrations of metals were found many fold times lower in air samples in comparison with crush samples of mosquito coil and cigarette. $\mathrm{Cd}$ was not detected in the present study, and our results contradict that of Karbon et al. [41]; they observed that $\mathrm{Pb}$ concentration
Fig. 3 Average of PM mass concentration for five brands of cigarette during burning and non-burning
1000

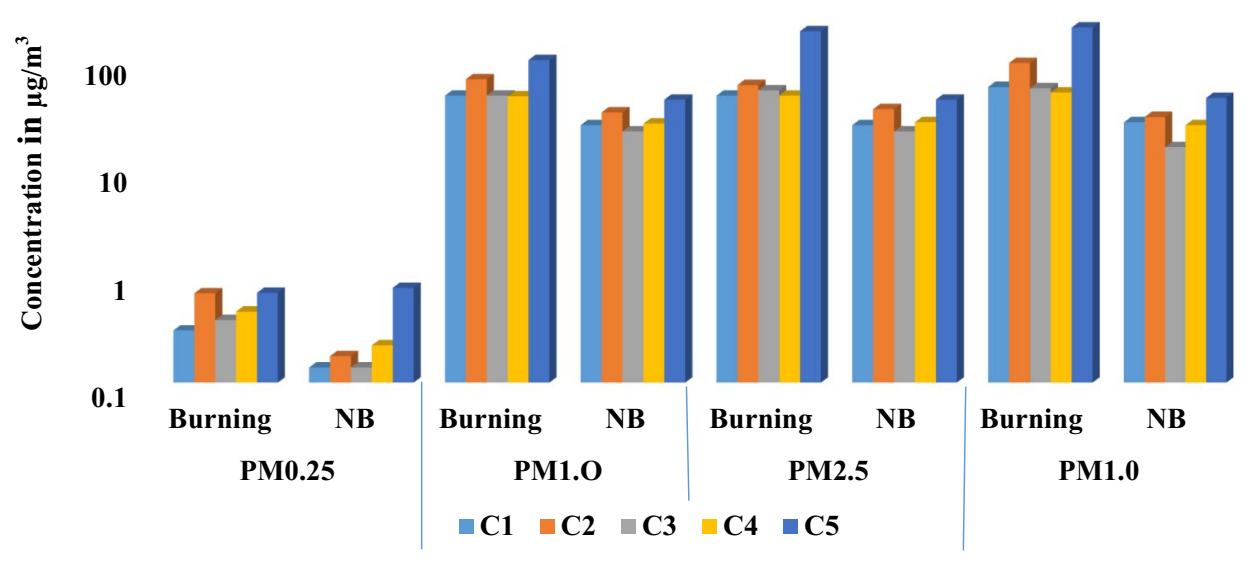



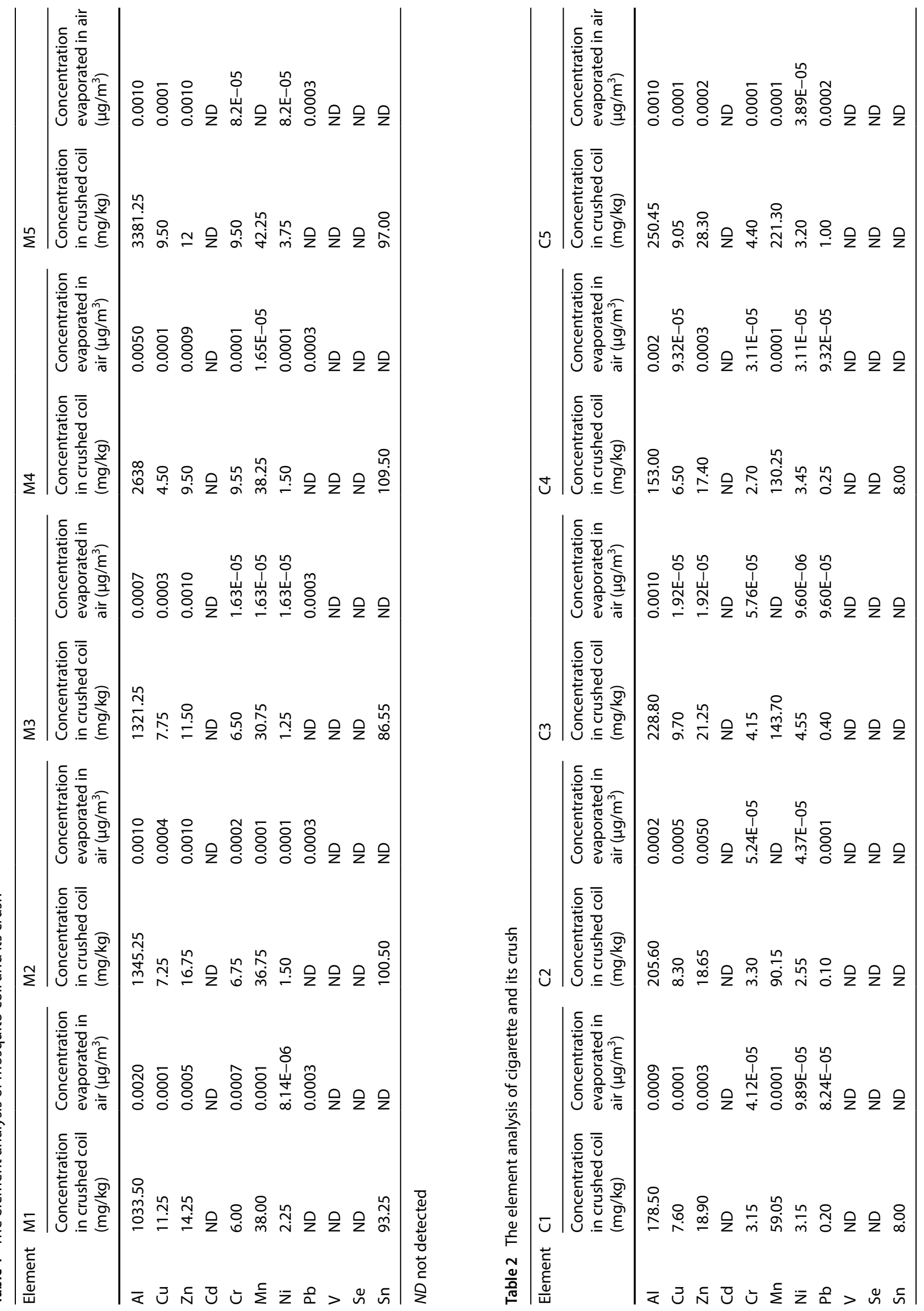
was the highest, followed by $\mathrm{Cr}$ and $\mathrm{Cd}$ in Iraq. Yebpella et al. [42] studied that when the cigarettes are burned during the process of smoking, metals are retained in the ash with about $70 \%$ transferred to the smoke. Phal [21] compared the results of cigarette powder, ash and the smoke which is released in the air, and the outcome implied that the content of heavy elements in the coil was at a faintly higher level as compared to that of the cigarette. Compared to other studies, [43] analyzed that Indian cigarettes contain lower amounts of heavy metals. Saffari et al. [44] analyzed the degree of exposure to different chemical agents and their emission rates were found quantified in the particles generated by e-cigarettes and normal cigarettes. In the present study, the elemental composition of five mosquito coils and cigarettes was sampled in a closed environmental chamber. Elemental analyses revealed that $\mathrm{Al}, \mathrm{Sn}, \mathrm{Mn}, \mathrm{Zn}, \mathrm{Cu}, \mathrm{Ni}$, $\mathrm{Cr}$, and $\mathrm{Pb}$ were all detected above the method detection limit. The heavy metals in the environment are of great concern because of their toxicity nature in the environment. Smoking of cigarettes and using mosquito coils to repel and kill vectors are critical. However, their improper use by consumers though may lead to other health problems that should not be ignored. Overall, the results of this study reveal that $\mathrm{Al}, \mathrm{Cr}$, and $\mathrm{Sn}$ were found higher in mosquito coils, whereas $\mathrm{Cu}, \mathrm{Zn}, \mathrm{Mn}, \mathrm{Ni}$, and $\mathrm{Pb}$ were higher in cigarette samples; particular elements may be attributed to the raw material used for manufacturing both (mosquito coil and cigarette). The element content emitted in air found out for mosquito coil and cigarette is within the Occupational Safety and Health Administration (OSHA) limits (http://www.osha. gov/pls/oshaweb/owadisp.show_document?p_table $=$ standards\&p_id=9992).

\subsection{Metal exposure dose}

Risk assessments can provide a great deal of information to an epidemiological exploration and particularly in the understanding of PM-allied health effects. They are often complicated yet controlling factors. We have used the risk assessment approach in order to ascertain boundary conditions for individual

Table 3 Exposure factors for dose models

\begin{tabular}{llllll}
\hline S.no. & Factor & Definition & Unit & Value (Adult) & References \\
\hline 1. & ED & $\begin{array}{c}\text { Exposure dura- } \\
\text { tion }\end{array}$ & Days & 2 & {$[33,34]$} \\
2. & AT & Average time & Days & ED $\times 365$ & \\
3. & IR & Inhalation rate & $\mathrm{m}^{3} /$ day & 20 & \\
4. & BW & Body weight & $\mathrm{kg}$ & 70 & \\
\hline
\end{tabular}

Table 4 Health risk from heavy metals in air samples of cigarettes

\begin{tabular}{|c|c|c|c|}
\hline Source & $A D D_{\text {pot }}$ & SFI & $R_{\mathrm{i}}$ \\
\hline \multicolumn{4}{|l|}{$\mathrm{PM}_{2.5}$} \\
\hline $\mathrm{C} 1$ & 0.029 & 11.2 & 0.324 \\
\hline $\mathrm{C} 2$ & 0.046 & & 0.515 \\
\hline $\mathrm{C} 3$ & 0.033 & & 0.369 \\
\hline $\mathrm{C} 4$ & 0.034 & & 0.380 \\
\hline C5 & 0.07 & & 0.784 \\
\hline \multicolumn{4}{|l|}{$\mathrm{Cu}$} \\
\hline $\mathrm{C} 1$ & $7.82 \mathrm{E}-8$ & & \\
\hline $\mathrm{C} 2$ & $3.91 \mathrm{E}-7$ & & \\
\hline $\mathrm{C} 3$ & $1.50 \mathrm{E}-8$ & & \\
\hline $\mathrm{C} 4$ & $7.29 \mathrm{E}-8$ & & \\
\hline C5 & $7.82 \mathrm{E}-8$ & & \\
\hline \multicolumn{4}{|l|}{$\mathrm{Zn}$} \\
\hline $\mathrm{C} 1$ & $2.34 \mathrm{E}-7$ & & \\
\hline $\mathrm{C} 2$ & $3.91 \mathrm{E}-6$ & & \\
\hline $\mathrm{C} 3$ & $1.50 \mathrm{E}-8$ & & \\
\hline $\mathrm{C} 4$ & $2.34 \mathrm{E}-7$ & & \\
\hline C5 & $1.56 \mathrm{E}-7$ & & \\
\hline \multicolumn{4}{|l|}{$\mathrm{Cr}$} \\
\hline $\mathrm{C} 1$ & $3.22 \mathrm{E}-8$ & 16.8 & $5.40 \mathrm{E}-7$ \\
\hline $\mathrm{C} 2$ & $4.10 \mathrm{E}-8$ & & $6.88 \mathrm{E}-7$ \\
\hline $\mathrm{C} 3$ & $4.50 \mathrm{E}-8$ & & $7.56 \mathrm{E}-7$ \\
\hline $\mathrm{C} 4$ & $2.43 \mathrm{E}-8$ & & $4.08 \mathrm{E}-7$ \\
\hline $\mathrm{C} 5$ & $7.82 \mathrm{E}-8$ & & $1.31 \mathrm{E}-6$ \\
\hline \multicolumn{4}{|l|}{$\mathrm{Ni}$} \\
\hline $\mathrm{C} 1$ & $7.74 \mathrm{E}-8$ & 0.672 & $5.20 \mathrm{E}-8$ \\
\hline $\mathrm{C} 2$ & $3.42 \mathrm{E}-8$ & & $2.29 \mathrm{E}-8$ \\
\hline $\mathrm{C} 3$ & 7.51E-9 & & $5.04 \mathrm{E}-9$ \\
\hline $\mathrm{C} 4$ & $2.43 \mathrm{E}-8$ & & $1.63 \mathrm{E}-8$ \\
\hline $\mathrm{C} 5$ & $3.04 \mathrm{E}-8$ & & $2.04 \mathrm{E}-8$ \\
\hline \multicolumn{4}{|l|}{$\mathrm{Pb}$} \\
\hline $\mathrm{C} 1$ & $6.45 \mathrm{E}-8$ & 0.016 & $1.03 \mathrm{E}-9$ \\
\hline $\mathrm{C} 2$ & $7.82 \mathrm{E}-8$ & & $1.25 \mathrm{E}-9$ \\
\hline $\mathrm{C} 3$ & $7.51 \mathrm{E}-8$ & & $1.20 \mathrm{E}-9$ \\
\hline $\mathrm{C} 4$ & $7.29 \mathrm{E}-8$ & & $1.16 \mathrm{E}-9$ \\
\hline C5 & $1.56 \mathrm{E}-7$ & & $2.49 \mathrm{E}-9$ \\
\hline
\end{tabular}

risks on a common population urban. Exposure factors for dose models for adults are shown in Table 3, and $A D D_{\text {pot }}$ and individual health risk from heavy metals in air samples of mosquito coil and cigarette are shown in Tables 4 and 5 . The trend of individual risk $\left(R_{\mathrm{i}}\right)$ of a health problem through $\mathrm{PM}_{2.5}$ was $\mathrm{M} 1>\mathrm{M} 3>\mathrm{M} 2>\mathrm{M} 4>\mathrm{M} 5$ in mosquito coil samples and $\mathrm{C} 5>\mathrm{C} 2>\mathrm{C} 4>\mathrm{C} 3>\mathrm{C} 1$ in cigarette samples. The maximum individual risk of health problem was found to be associated with $\mathrm{Cr}$ and minimum with $\mathrm{Pb}$ in mosquito coil samples and cigarette samples though it was below the threshold levels. Results showed the 
Table 5 Health risk from heavy metals in air samples of mosquito coils

\begin{tabular}{|c|c|c|c|}
\hline Source & $A D D_{\text {pot }}$ & SFI & $R_{\mathrm{i}}$ \\
\hline \multicolumn{4}{|l|}{$\mathrm{PM}_{2.5}$} \\
\hline M1 & 0.286 & 11.2 & 3.20 \\
\hline M2 & 0.14 & & 1.56 \\
\hline M3 & 0.177 & & 1.98 \\
\hline M4 & 0.072 & & 0.80 \\
\hline M5 & 0.015 & & 0.16 \\
\hline \multicolumn{4}{|l|}{$\mathrm{Cu}$} \\
\hline M1 & $7.82 \mathrm{E}-8$ & & \\
\hline M2 & $3.13 \mathrm{E}-7$ & & \\
\hline M3 & $2.34 \mathrm{E}-7$ & & \\
\hline M4 & $7.82 \mathrm{E}-8$ & & \\
\hline M5 & $7.82 \mathrm{E}-8$ & & \\
\hline \multicolumn{4}{|l|}{$\mathrm{Zn}$} \\
\hline M1 & $3.91 \mathrm{E}-7$ & & \\
\hline M2 & $7.82 \mathrm{E}-7$ & & \\
\hline M3 & $7.82 \mathrm{E}-7$ & & \\
\hline M4 & $7.04 \mathrm{E}-7$ & & \\
\hline M5 & $7.82 \mathrm{E}-7$ & & \\
\hline \multicolumn{4}{|l|}{$\mathrm{Cr}$} \\
\hline M1 & $5.47 \mathrm{E}-7$ & 16.8 & $9.18 \mathrm{E}-6$ \\
\hline M2 & $1.56 \mathrm{E}-7$ & & $2.62 E-6$ \\
\hline M3 & $1.27 \mathrm{E}-8$ & & $2.13 \mathrm{E}-7$ \\
\hline M4 & $7.82 \mathrm{E}-8$ & & $1.31 \mathrm{E}-6$ \\
\hline M5 & $6.41 \mathrm{E}-8$ & & $1.07 \mathrm{E}-6$ \\
\hline \multicolumn{4}{|l|}{$\mathrm{Ni}$} \\
\hline M1 & $6.37 \mathrm{E}-9$ & 0.672 & $4.28 \mathrm{E}-9$ \\
\hline M2 & $7.82 \mathrm{E}-8$ & & $5.25 \mathrm{E}-8$ \\
\hline M3 & $1.27 \mathrm{E}-8$ & & $8.53 \mathrm{E}-9$ \\
\hline M4 & $7.82 \mathrm{E}-8$ & & $5.25 \mathrm{E}-8$ \\
\hline M5 & $6.41 \mathrm{E}-8$ & & $4.30 \mathrm{E}-8$ \\
\hline \multicolumn{4}{|l|}{$\mathrm{Pb}$} \\
\hline M1 & $2.34 \mathrm{E}-7$ & 0.016 & $3.74 \mathrm{E}-9$ \\
\hline M2 & $2.34 \mathrm{E}-7$ & & $3.74 \mathrm{E}-9$ \\
\hline M3 & $2.34 \mathrm{E}-7$ & & $3.74 \mathrm{E}-9$ \\
\hline M4 & $2.34 \mathrm{E}-7$ & & $3.74 \mathrm{E}-9$ \\
\hline M5 & $2.34 \mathrm{E}-7$ & & $3.74 \mathrm{E}-9$ \\
\hline
\end{tabular}

concentrations of $\mathrm{Ni}$ in air samples are alarming and higher than dangerous values.

\subsection{Assessment of non-carcinogenic health risk}

The result for $\mathrm{HQ}$ is given in Fig. 4. The average $\mathrm{HQ}$ value for the adults for all the heavy metals is well under the safe limit, which means there is no non-carcinogenic unfavorable impact on adults [34]. The HQs value decreased in the order of $\mathrm{Zn}<\mathrm{Ni}<\mathrm{Cu}<\mathrm{Cr}<\mathrm{Pb}$ in mosquito coils and $\mathrm{Ni}<\mathrm{Zn}<\mathrm{Cu}<\mathrm{Cr}<\mathrm{Pb}$ in cigarette samples. The results concluded that the $\mathrm{HQ}$ values for all metals were below 1 . For non-carcinogens, there subsists the assumption of the threshold, below which there is no toxic response.

\subsection{Excess cancer risks (ECRs)}

ECRs for carcinogenic risk of metals through inhalation pathway have been calculated as described earlier by using Eq. (1), and results are presented in Table 6. The decreasing order of excess cancer risk (ECR) for the carcinogenic elements pursues the similar trend for both cigarettes and mosquito coil in adults: $\mathrm{Pb}<\mathrm{Ni}<\mathrm{Cr}$ The total average ECRs for mosquito coil and cigarettes are $2.18 \times 10^{-7}$ and $5.03 \times 10^{-8}$ which were found to be well below the acceptable level $\left(10^{-4}\right.$ and $\left.10^{-6}\right)$ for adults although we found the values of the above metals more in mosquito coil samples in comparison with cigarette samples, and the present study shows no health hazards. It was the first effort to assess exposure to heavy metals and uncertainties could not be neglected. Further studies should lay down exposure parameters which could mull over local human activities mode to give more authentic risk assessment outcomes.

\subsection{SEM characterization of $\mathrm{PM}_{2.5}$ samples}

Morphological characteristics (texture, edges, and size) of ambient atmospheric particles collected from different brands of mosquito coils and cigarette were compared in order to determine their origin. We take two brands of mosquito coil and two brands of a cigarette according to the maximum and minimum $\mathrm{PM}_{2.5}$ concentration for SEM analysis. In cigarette samples, the minimum $\mathrm{PM}_{2.5}$ concentration was found in sample $\mathrm{C} 1$ and the maximum was found in $\mathrm{C} 5$, whereas in mosquito coil samples the minimum $\mathrm{PM}_{2.5}$ concentration was found in sample $\mathrm{M} 5$ and the maximum was found in M1. Without burning of mosquito coil and cigarette samples in experiment chamber, we found the branched clusters of soot particles embedded in the filter paper with tubular shape probably containing $\mathrm{Si}-\mathrm{O}$ as shown in Fig. 5a (blank filter paper). $\mathrm{SiO}_{2}$ particles (commonly called silica) are characterized by high content $\mathrm{Si}$ and $\mathrm{O}$. Figure 6a shows a tubular structure which was collected at the without burning phase, the pure silica particles have a natural origin. Figure $6 \mathrm{~b}$ shows an irregularly shaped particle characterized by a complex mixture of the carbon-rich particle. Carbon particle with nearly spherical morphology and porous surface configuration dominated by $C$ and $\mathrm{O}$ and spherical shape probably contain $\mathrm{Al}-\mathrm{Si}-\mathrm{O}$ as illustrated in Fig. 6c.

Analysis of individual particles collected from experimental chamber during burning and after burning of 
Fig. 4 Hazards quotient $(\mathrm{HQ})$ for adults respective to metals exposure pathway

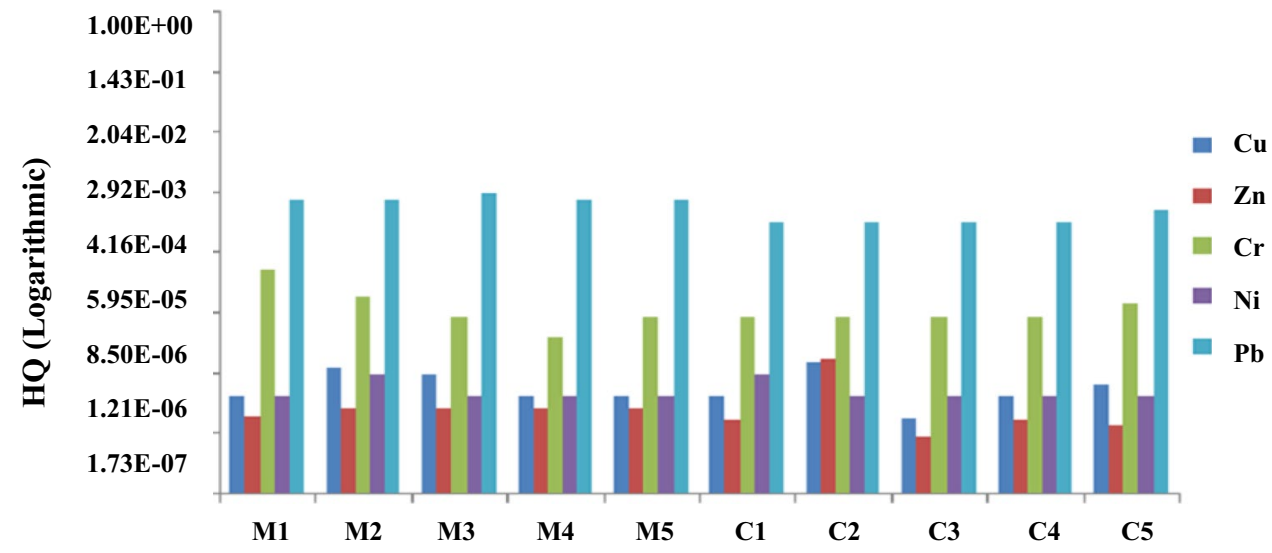

Table 6 Excess cancer risks (ECR) of carcinogenic elements in mosquito coils and cigarette samples

\begin{tabular}{|c|c|c|c|c|c|}
\hline Source & Carcinogen group & $\operatorname{IUR}\left(\mu \mathrm{g} / \mathrm{m}^{3}\right)^{\mathrm{a}}$ & $\begin{array}{l}\text { Excess cancer risk of mos- } \\
\text { quito coil samples }\end{array}$ & Source & $\begin{array}{l}\text { Excess cancer risk of } \\
\text { cigarettes samples }\end{array}$ \\
\hline \multicolumn{6}{|l|}{$\mathrm{Cr}$} \\
\hline M1 & A (Human carcinogen) & 0.012 & $6.90 \mathrm{E}-7$ & $\mathrm{C} 1$ & $4.06 \mathrm{E}-8$ \\
\hline M2 & & & 1.97E-7 & $\mathrm{C} 2$ & $5.16 \mathrm{E}-8$ \\
\hline M3 & & & $1.60 \mathrm{E}-8$ & $\mathrm{C} 3$ & $4.73 \mathrm{E}-8$ \\
\hline M4 & & & $9.8 \mathrm{E}-8$ & $\mathrm{C} 4$ & $2.55 \mathrm{E}-8$ \\
\hline M5 & & & $8.08 \mathrm{E}-8$ & C5 & $8.21 \mathrm{E}-8$ \\
\hline \multicolumn{6}{|l|}{$\mathrm{Ni}$} \\
\hline M1 & A (Human carcinogen) & 0.00024 & $1.60 \mathrm{E}-10$ & $\mathrm{C} 1$ & $1.95 \mathrm{E}-9$ \\
\hline M2 & & & 1.97E-9 & $\mathrm{C} 2$ & $8.62 \mathrm{E}-10$ \\
\hline M3 & & & $3.21 \mathrm{E}-10$ & $\mathrm{C} 3$ & 1.57E-10 \\
\hline M4 & & & 1.97E-9 & $\mathrm{C} 4$ & $5.11 \mathrm{E}-10$ \\
\hline M5 & & & $1.61 \mathrm{E}-9$ & $\mathrm{C} 5$ & $6.39 \mathrm{E}-10$ \\
\hline \multicolumn{6}{|l|}{$\mathrm{Pb}$} \\
\hline M1 & B2 (Probable human carcinogen) & 0.000012 & $2.95 \mathrm{E}-10$ & $\mathrm{C} 1$ & $8.12 \mathrm{E}-11$ \\
\hline M2 & & & $2.95 \mathrm{E}-10$ & $\mathrm{C} 2$ & $9.86 \mathrm{E}-11$ \\
\hline M3 & & & $2.95 \mathrm{E}-10$ & $\mathrm{C} 3$ & $7.89 \mathrm{E}-11$ \\
\hline M4 & & & $2.95 \mathrm{E}-10$ & $\mathrm{C} 4$ & $7.66 \mathrm{E}-11$ \\
\hline M5 & & & $2.95 \mathrm{E}-10$ & $\mathrm{C} 5$ & $1.64 \mathrm{E}-10$ \\
\hline
\end{tabular}

${ }^{\text {a }}$ Values taken from IRIS (Integrated Risk Information System) [45]

mosquito coil and cigarettes samples shows the irregular-shaped particle characterized by complex mixture of carbon-rich particle containing varying amounts of metals $\mathrm{Al}, \mathrm{Cu}, \mathrm{Zn}, \mathrm{Cr}, \mathrm{Mn}, \mathrm{Ni}, \mathrm{Pb}$ which was confirmed by ICP-AES technique for sample $\mathrm{C} 1$ in Fig. 7a. Similar results are shown in Fig. $9 \mathrm{~b}$ for sample M5 and Fig. 10b for sample M1. Figure $7 \mathrm{~b}$ shows the nearly rectangular shape probably containing aluminosilicate for sample $\mathrm{C} 1$. Similar results are shown in Fig. $8 \mathrm{c}$ for sample C5. Figure 8a shows the $\mathrm{Cr}$ in combination with, $\mathrm{Mn}$, $\mathrm{Si}$, and $\mathrm{O}$ which was confirmed by ICP-AES technique. Carbon particle with nearly spherical morphology was dominated by $\mathrm{O}$ and $\mathrm{C}$ as shown in Fig. $8 \mathrm{~b}$ for sample $\mathrm{C} 5$.
Similar results are shown in Fig. 9a for sample M5 and Fig. 10a for sample M1. In cigarette sample C5, the particles were of irregular, nearly spherical, and of rectangular shape, while in sample M1 (mosquito coil) the particle shapes were nearly spherical and irregular in nature In, cigarette sample $\mathrm{C} 1$, the particles were of irregular and nearly rectangular shape, whereas in sample M5 (mosquito coil) the particle shapes were nearly spherical and irregular. The surface morphology of the particles collected from the chamber was indicated to have branched aggregates of carbonaceous matter. They are ubiquitous in nature because of their origin in burning processes, where they can be formed at temperatures 
Fig. 5 Blank quartz fiber filter

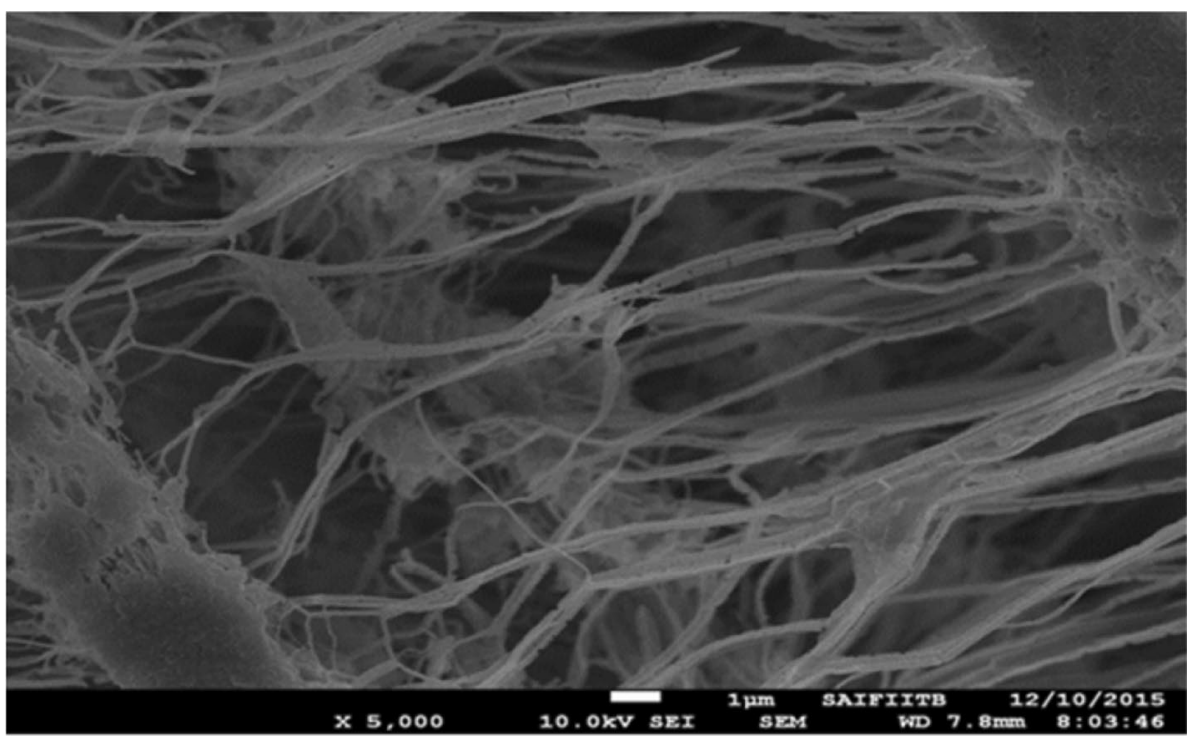

Fig. 6 SEM images of without burning phase (mosquito coil and cigarette): $\mathbf{a}$ branched cluster of soot particles embedded in the filter paper with tubular shape probably containing $\mathrm{Si}-\mathrm{O}, \mathbf{b}$ an irregularshaped particles characterized by complex mixture of carbonrich particle, c carbon particle with nearly spherical morphology dominated by $\mathrm{C}, \mathrm{O}$ and spherical probably containing $\mathrm{Al}-\mathrm{Si}-\mathrm{O}$, $\mathbf{d}$ a single carbon particle with nearly spherical morphology dominated by $C$ and $\mathrm{O}$
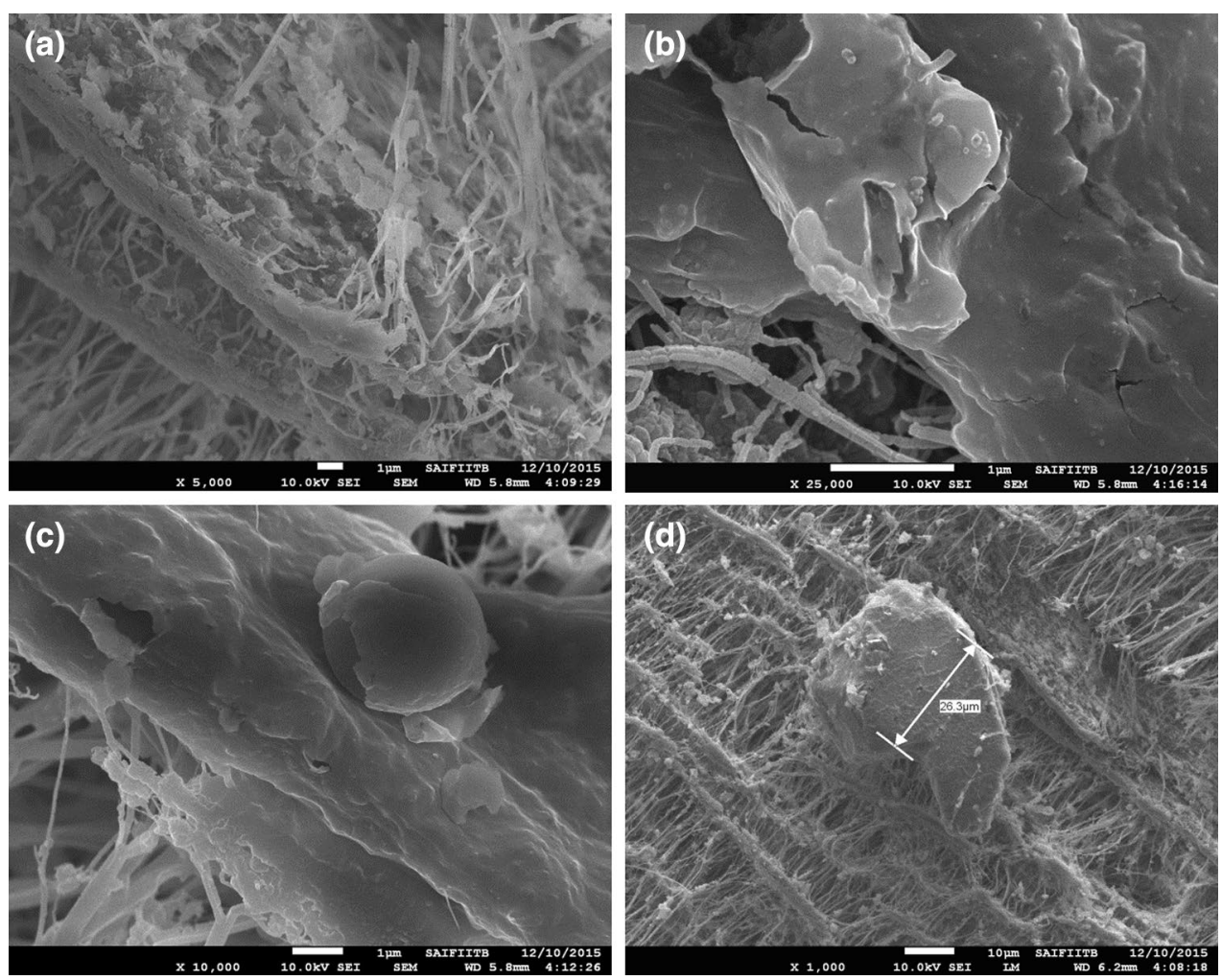

around $200^{\circ} \mathrm{C}$. These particles enter the atmosphere as a result of incomplete combustion processes. Various studies have reported that the morphology of carbonaceous particle originated from burning processes is diverse from soot chains to complex structures, which depends on burning conditions and atmospheric processes [46-50]. Cu, Zn, and Mn are also found in air samples of mosquito coils.

\section{Conclusion}

The results of this study reveal that burning of sample M1 has the highest emission of the PM and sample M5 has the least in all the brands of mosquito coil, and burning of sample $\mathrm{C} 5$ has the highest emission of the PM and sample $\mathrm{C} 1$ has the least in all the brands of cigarette. The maximum concentration of $\mathrm{Al}$ was found in 

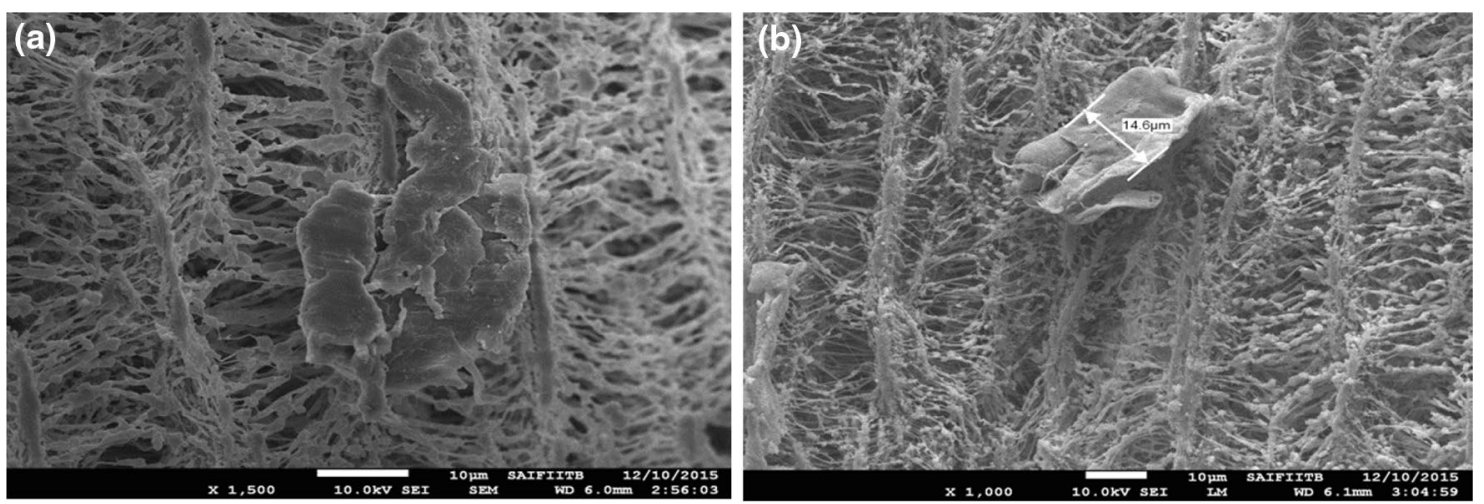

Fig. 7 SEM images of cigarette sample C1 during burning phase: a an irregular-shaped particle characterized by complex mixture of carbon-rich particles, b nearly rectangular shape probably containing aluminosilicate
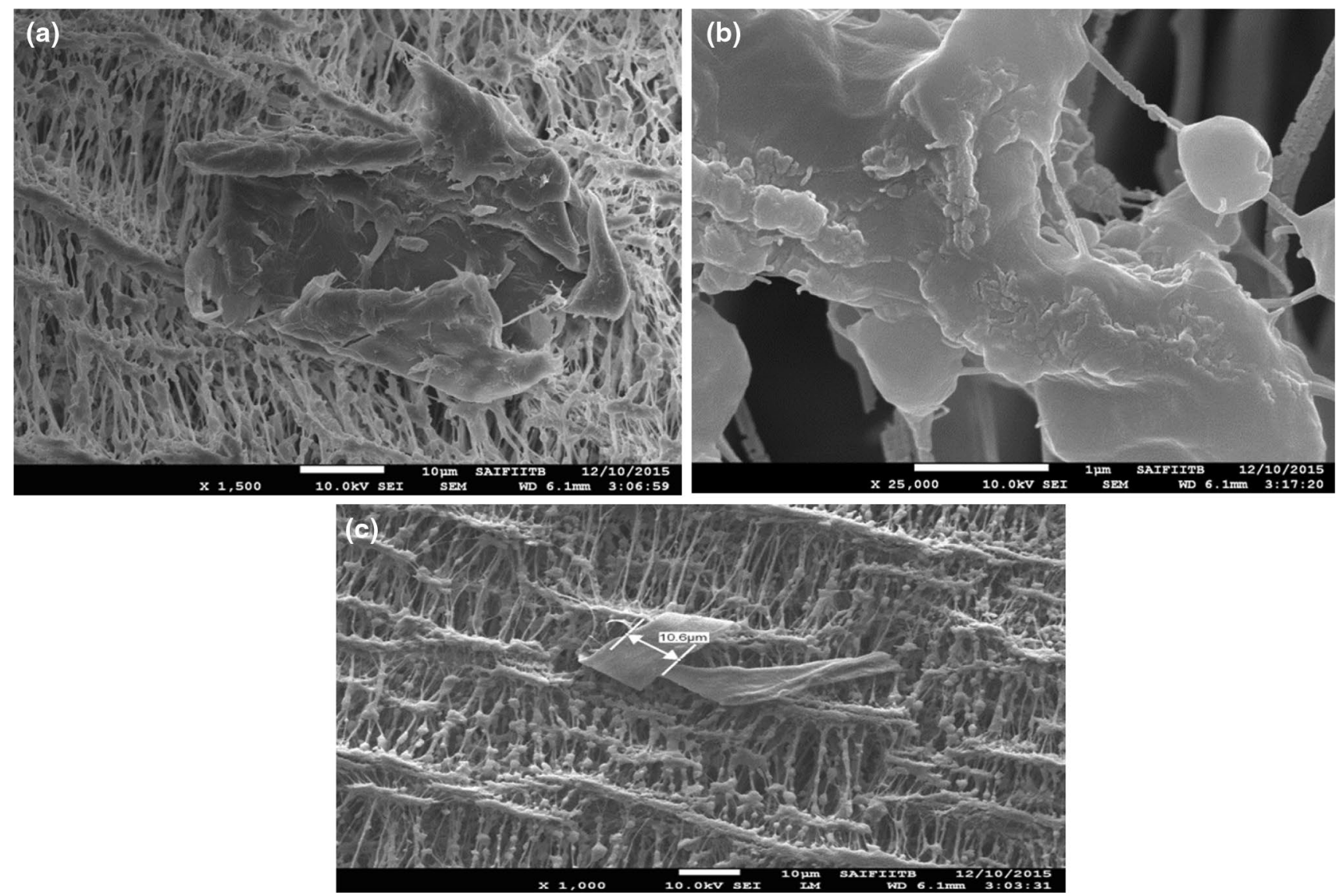

Fig. 8 SEM images of cigarette sample C5 during burning phase: a an irregular shape containing $\mathrm{Cr}$ in combination with $\mathrm{Mn}$, Si, and O, $\mathbf{b}$ carbon particle with nearly spherical morphology dominated by $\mathrm{C}$ and $\mathrm{O}$, c nearly rectangular shape probably containing aluminosilicate

crush and air samples of mosquito coil and cigarette. The minimum concentration of $\mathrm{Ni}$ and $\mathrm{Pb}$ was observed in crush samples of mosquito coil and cigarette, respectively, whereas $\mathrm{Mn}$ was found in minimum concentration in air samples of mosquito coil and cigarette. The trend of individual risk $\left(R_{\mathrm{i}}\right)$ of a health problem through
$\mathrm{PM}_{2.5}$ was $\mathrm{M} 1>\mathrm{M} 3>\mathrm{M} 2>\mathrm{M} 4>\mathrm{M} 5$ in mosquito samples and $\mathrm{C} 5>\mathrm{C} 2>\mathrm{C} 4>\mathrm{C} 3>\mathrm{C} 1$ in cigarette samples. The maximum individual risk of health problem was found to be associated with $\mathrm{Cr}$ and the minimum with mosquito coil samples and cigarette samples though it was below the threshold levels. Values for adults are

\section{SN Applied Sciences}



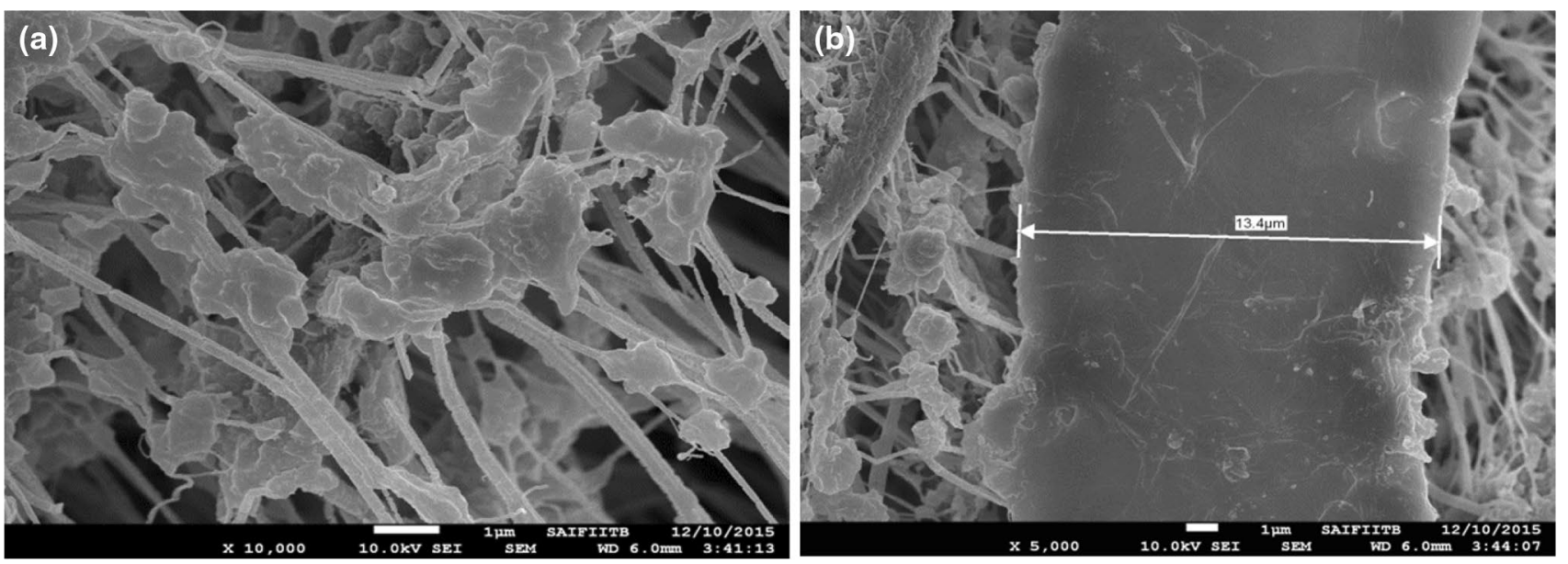

Fig. 9 SEM images of mosquito coil sample M5 during burning phase: a branched cluster of soot particles embedded in the filter paper with carbon particle with nearly spherical morphology domi- nated by $\mathrm{C}$ and $\mathrm{O}$, $\mathbf{b}$ an irregular-shaped particle characterized by complex mixture of carbon-rich particles
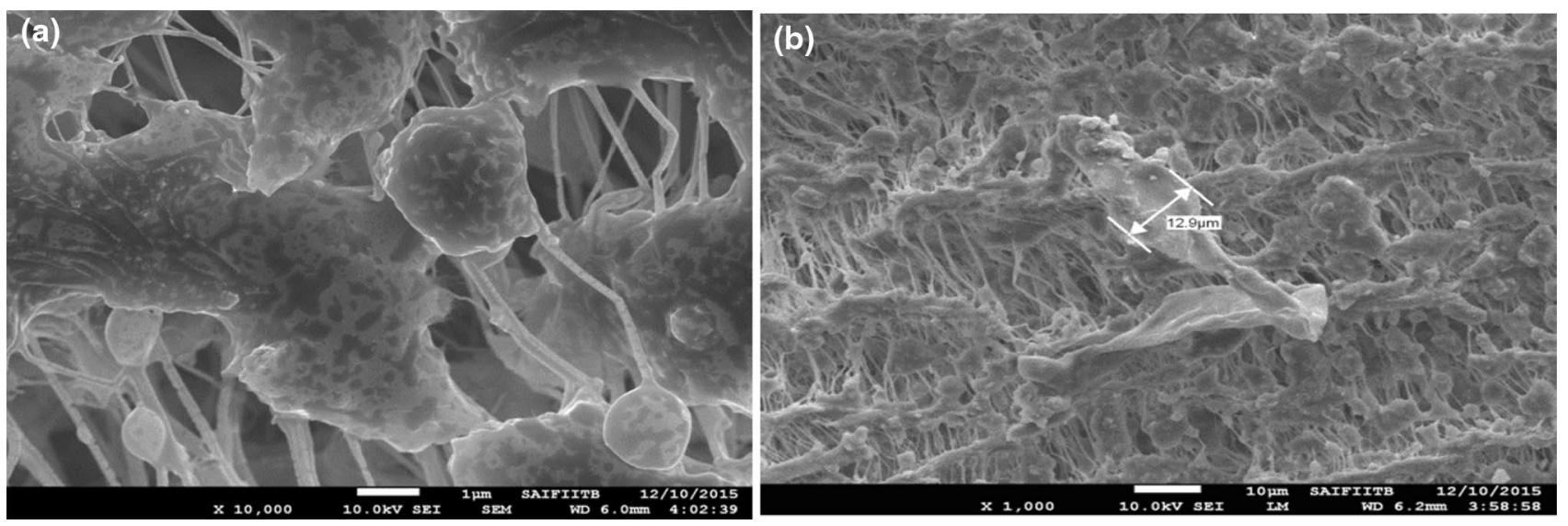

Fig. 10 SEM images of mosquito coil sample M1 during burning phase: a carbon particles with nearly spherical morphology dominated by $\mathrm{C}$ and $\mathrm{O}, \mathbf{b}$ an irregular-shaped particles characterized by complex mixture of carbon-rich particle

well under the safe limit $(\mathrm{HI}<1)$ indicating non-cancer risk from heavy metals. We found the cancer risk to be well below the acceptable level $\left(10^{-4}-10^{-6}\right)$ for adults. Further studies should put aside exposure parameters which could consider local human activities mode to give more authentic risk assessment outcomes. This is a short-term study. The time of exposure was very limited, and the concentration of metals was below the limits, but it is believed that if the exposure duration is larger, then the concentration of metals would increase; so keeping this fact in mind, we have performed human risk assessment by taking the standard methods in our study. Further study will help to monitor on the emissions of other toxic pollutants such as PAHs, VOCs in both gas phase and particulate phase within smoke produced by cigarettes and mosquito coil and to assess the likely exposure and impact on human health. The more in-depth investigation should also be conducted in actual furnished rooms in a real apartment to evaluate the effects of smoke generated by smoking in an actual residential environment.

Acknowledgements The authors acknowledge the University Grant Commission (UGC), New Delhi, for financial support (Project No.: F. 15-45/12 (SA-II) and MRP-Major-Chem-2013-25775). The authors would akin to convey their special appreciation to Department of Chemistry, Dr. Bhim Rao Ambedkar University, Agra, India, for providing all necessary amenities required for this work.

\section{Compliance with ethical standards}

Conflict of interest On behalf of all authors, the corresponding author states that there is no conflict of interest. 


\section{References}

1. Massey DD, Habil M, Taneja A (2016) Particles in different indoor microenvironments-its implications on occupants. Build Environ 106:237-244

2. Taneja A, Saini R, Masih A (2008) Indoor air quality of houses located in the urban environment of Agra, India. Ann NY Acad Sci 1140:228-245

3. Kulshrestha A, Satsangi PG, Masih J, Taneja A (2009) Metal concentration of $\mathrm{PM}_{2.5}$ and $\mathrm{PM}_{10}$ particles and seasonal variations in an urban and rural environment of Agra, India. Sci Total Environ 407:6196-6204

4. Saini R, Singh P, Awasthi BB, Kumar K, Taneja A (2014) Ozone distributions and urban air quality during summer in Agra-a world heritage site. Atmos Pol Res 5(4):796-804

5. Saini R, Taneja A, Singh P (2017) Surface ozone scenario and air quality in the north-central part of India. J Environ Sci 59:72-79

6. Singh P, Saini R, Taneja A (2014) Physiochemical characteristic ofPM $_{25}$ : low, middle and high-income group homes in Agra, India-a case study. Atmos Pollut Res 5:352-360

7. Kankaria A, Nongkynrih B, Gupta SK (2014) Indoor air pollution in india: implications for health and its control. Indian J Community Med 39:203-207

8. Begum BA, Paul SK, Hossain MD, Biswas SK, Opke PK (2009) Indoor air pollution from particulate matter emissions in a different household in rural areas in Bangladesh. Build Environ 44:898-903

9. Gadkari NM, Pervez S (2008) Source apportionment of personal exposure of fine particulates among school communities in India. Environ Monit Assess 142:227-241

10. Wu D, Landsberger Larson SM (1997) Determination of the elemental distribution in cigarette components and smoke by instrumental neutron activation analysis. J Radioanal Nucl Chem 217:77-82

11. Lal PG, Wilson Nevin C, Gupta PC (2012) Attributable deaths from smoking in the last 100 years in India. Curr Sci 103:1085-1090

12. Wang B, Ho Steven Sai Hang, Ho Kin Fai, Huang Yu, Chan ChiSing, Feng Natale Sin Yau, Simon Ho Sai IP (2012) An environmental chamber study of the characteristics of air pollutants released from environmental tobacco smoke. Aerosol Air Qual Res 12:1269-1281

13. Onojah PK, Daluba NE, Odin EM (2015) Investigation of heavy metals in selected samples of cigarette randomly purchased from local markets in Anyigba and its environment and tobacco leaves grown in Kogi State, Nigeria. Int J Innov Res Technol Sci 3:1-7

14. Kazi TG, Jalbani N, Arain MB, Jamali MK, Afridi HI, Shah AQ (2009) Determination of toxic elements in different brands of cigarette by atomic absorption spectrometry using ultrasonically assisted acid digestion. Environ Monit Assess 154:155-167

15. Pappas RS, Polzin GM, Zhang L, Watson CH, Paschal DC, Ashley DL (2006) Cadmium lead, and thallium in mainstream tobacco smoke particulate. Food Chem Toxicol 44:714-723

16. Hynes DR (2007) Trace element in vegetable and soil in domestic gardens around smelting complex. Environ Pollut 9:211-221

17. Moir D, Rickert WS, Levasseur G, Larose $Y$, Maertens $R$, White $P$, Desjardins SA (2008) Comparison of mainstream and side stream marijuana and tobacco cigarette smoke produced under two machine smoking conditions. Chem Res Toxicol 21:494-502

18. Piadé J-J, Jaccard G, Dolka C, Belushkin M, Warnock S (2015) Differences in cadmium transfer from tobacco to cigarette smoke, compared to arsenic or lead. Toxicol Rep 2:12-26

19. Behera SN, Xian H, Balasubramanian R (2014) Human health risk associated with exposure to toxic elements in mainstream and side stream cigarette smoke. Sci Total Environ 472:947-956
20. Elinder CG, Kjellstom T, Lind B, Linnman I, PiscatorM Sundstedt K (1983) Cadmium exposure from smoking cigarettes; variations with time and country where purchased. Environ Res 32:220-227

21. Phal DA (2011) A comparative study of elemental analysis in mosquito repellent coil and cigarette. Smoke Int J Pharm Biol Sci 1:462-467

22. Lin T-S, Shen F-M (2005) Trace metals in mosquito coil smoke. Bull Environ Contam Toxicol 74:184-189

23. Lee SC, Wang B (2006) Characteristics of emissions of air pollutants from mosquito coils and candles burning in a large environmental chamber. Atmos Environ 40:2128-2138

24. Liu WK, Zhang J, Hashim JH, Jalaludin J, Hashim Z, Goldstein BD (2003) Mosquito coil emissions and health implications. Environ Health Perspect 111:1454-1460

25. Krieger RI, Dinoff TM, Zhang X (2003) octachlorodipropyl ether (S-2) mosquito coils are inadequately studied for residential use in Asia and illegal in the United States. Environ Health Perspect 111:1439-1442

26. Agbandji L, Patrick AE, Gbago GB, Koumolou L, Adisso S, Guedenon P, Ahodjide S, Sinsin B, Boko M (2012) Comparison of heavy metals contents for some cigarettes brands. Am J Pharmacol Toxicol 17:149-153

27. Jung MC, Thornton I, Chon HT (1998) Arsenic, cadmium, copper, lead and zinc concentrations in cigarettes produced in Korea and the United Kingdom. Environ Technol 19:237-241

28. Roy AA, Baxla SP, Gupta T, Bandyopadhyaya R, Tripathi SN (2009) Particles emitted from indoor combustion sources: size distribution measurement and chemical analysis. Inhal Toxicol 21:837-848

29. Kumar R, Gupta N, Kumar D, Mavi AK, Singh K, Kumar M (2014) Monitoring of indoor particulate matter during the burning of mosquito coil, incense sticks and dhoop. Indian J Allergy Asthma Immunol 28:68-73

30. Varshney P, Saini R, Taneja A (2016) Trace element concentration in fine particulate matter (PM2.5) and their bioavailability in different microenvironments in Agra, India: a case study. Environ Geochem Health 38:593-605

31. Engida AM (2007) Levels of trace metals in cigarettes commonly sold in Ethiopia. The project, Addis Ababa University, School of Graduate Studies, Addis Ababa

32. Liu WK, Wong MH, Mui YL (1987) Toxic effects of mosquito coil (A mosquito repellent) smoke on rats I. Properties of the mosquito coil and its smoke. Toxicol Lett 39:223-230

33. Greene NA, Vernon R, Morris VR (2006) Assessment of public health risks associated with atmospheric exposure to $\mathrm{PM}_{2.5}$ in Washington, DC, USA. Int J Environ Res Public Health 3:86-97

34. Izhar S, Goel A, Chakraborty A, Gupta T (2016) Annual trends in the occurrence of submicron particles in the ambient air and health risk posed by particle bound metals. Chemosphere 146:582-590

35. Parveen R, Saini R, Taneja A (2018) Chemical characterization and health risk assessment of soil and airborne particulates metals and metalloids in populated semiarid region, Agra, India. Environ Geochem Health 40(5):2021-2035

36. Zheng N, Liu J, Wang Q, Liang Z (2010) Health risk assessment of heavy metal exposure to street dust in the zinc smelting district, Northeast of China. Sci Total Environ 408:726-733

37. US EPA (2011) Risk Assessment Guidance for Superfund. In: Part A (ed) Human health evaluation manual; Part E, supplemental guidance for dermal risk assessment; Part F, supplemental guidance for inhalation risk assessment, I

38. Hu X, Zhang Y, Ding Z, Wang T, Lian H, Sun Y, Wu J (2012) Bioaccessibility and health risk of arsenic and heavy metals (Cd Co, $\mathrm{Cr}, \mathrm{Cu}, \mathrm{Ni}, \mathrm{Pb}, \mathrm{Zn}$, and $\mathrm{Mn}$ ) in TSP and PM2.5 in Nanjing, China. Atmos Environ 57:146-152 
39. WHO (2006) Fuel for life: household energy and health. WHO, Geneva

40. Iwuoha GN, Oghu El, Onwuachu UI (2013) Levels of selected heavy metals in some brands of cigarettes marketed in University of Port Harcourt, Rivers State. J Appl Sci Environ Manag 17:561-564

41. Karbon MH, Ali FH, Hasan EJ, Znad DE, Zamil SK, Lafi AF (2015) Evaluation of the level of some heavy metals in tobacco of domestic and imported cigarette brands used in Iraq. Baghdad Sci J 12:582-590

42. Yebpella GG, Shallangwa GA, Hammuel C, Magomya A, Oladipo MOA, Nok AN, Bonire JJ (2011) Heavy metal content of different brands of cigarettes commonly smoked in Nigeria and its toxicological implications. Pac J Sci Technol 12:356-362

43. Janardhana N, Kofod M, Isenbeck-Schröter M, Müller G (1999) Heavy metals content of Indian cigarettes. Toxicol Environ Chem 72:215-219

44. Saffari A, Daher N, Ruprecht A, Marco CD, Pozzi P, Boffi R, Hamad SH, Shafer MM, Schauer JJ, Westerdahl D, Sioutas C (2014) Particulate metals and organic compounds from electronic and tobacco-containing cigarettes: comparison of emission rates and secondhand exposure. Environ Sci Process Impacts $16: 2259-2267$
45. IRIS (Integrated Risk Assessment System) (1995) United States Environmental Protection Agency. https://www.epa.gov/IRIS/

46. Cong Z, Kang S, Dong S, Zhang Y (2009) Individual particle analysis of atmospheric aerosols at Nam Co, Tibetan Plateau. Aerosol Air Qual Res 9:323-331

47. Pósfai M, Buseck PR (2010) Nature and climatic effects of individual tropospheric aerosol particles. Annu Rev Earth Planet Sci 38:17-43

48. Tumolva L, Park JY, Kim J, Miller AL, Chow JC, Watson JG, Park K (2010) Morphological and elemental classification of freshly emitted soot particles and atmospheric ultrafine particles using the TEM/EDS. Aerosol Sci Technol 44:202-215

49. Gautam S, Prasad N, Patra AK, Prusty BK, Singh P, Pipal AS, Saini R (2016) Characterization of PM 2.5 generated from opencast coal mining operations: a case study of Sonepur Bazari Opencast Project of India. Environ Technol Innov 6:1-10

50. Roy D, Gautam S, Singh P, Singh G, Das BK, Patra AK (2016) Carbonaceous species and physicochemical characteristics of PM10 in coal mine fire area-a case study. Air Qual Atmos Health 9(4):429-437

Publisher's Note Springer Nature remains neutral with regard to jurisdictional claims in published maps and institutional affiliations. 